\section{Southern African Development Community (SADC)}

The Southern African Development Co-ordination Conference (SADCC), the precursor of the Southern African Development Community (SADC), was formed in Lusaka, Zambia on 1 April 1980, following the adoption of the Lusaka Declaration-Southern Africa: Towards Economic Liberation-by the nine founding member states.

Members. The nine founder member countries were Angola, Botswana, Lesotho, Malawii, Mozambique, Swaziland, Tanzania, Zambia and Zimbabwe. The Democratic Republic of the Congo, Madagascar, Mauritius, Namibia, the Seychelles and South Africa have since joined. The Seychelles left in July 2004 but rejoined in Aug. 2007. As a result there are now 15 members.

Aims and Activities. SADC's Common Agenda includes the following: the promotion of sustainable and equitable economic growth and socio-economic development that will ensure poverty alleviation with the ultimate objective of its eradication; the promotion of common political values, systems and other shared values that are transmitted through institutions that are democratic, legitimate and effective; and the consolidation and maintenance of democracy, peace and security.

In contrast to the country-based co-ordination of sectoral activities and programmes, SADC has now adopted a more centralized approach through which the 21 sectoral programmes are grouped into four clusters; namely: Trade, Industry, Finance and Investment; Infrastructure and Services; Food, Agriculture and Natural Resources; Social and Human Development and Special Programmes.

SADC has made significant progress in implementing its integration agenda since the 1992 Treaty came into force. Since then, 23 Protocols to spearhead the sectoral programmes and activities have been signed. The following protocols have entered into force: Immunities and Privileges; Combating Illicit Drugs; Energy; Transport, Communications and Meteorology; Shared Watercourse Systems; Mining; Trade; Education and Training; Tourism; Health, Wildlife Conservation and Law Enforcement; Tribunal and the Rules of Procedure; Revised Protocol on Shared Watercourses; Amendment Protocol on Trade; Politics, Defense and Security Co-operation; Control of Firearms, Ammunition and Other Related Materials in SADC; Fisheries.

Official languages: English, French, Portuguese.

Headquarters: Private Bag 0095, Gaborone, Botswana.

Website: http://www.sadc.int

email: registry@sadc.int

Executive Secretary: Tomaz Augusto Salomão (Mozambique).

\section{West African Development Bank (BOAD)}

The West African Development Bank (Banque Ouest Africaine de Développement) was established in Nov. 1973 by an Agreement signed by the member states of the West African Monetary Union (UMOA), now the West African Economic and Monetary Union (UEMOA).

Aims. To promote balanced development of the States of the Union and to achieve West African economic integration.

Members. Benin, Burkina Faso, Côte d'Ivoire, Guinea-Bissau, Mali, Niger, Senegal, Togo.
Official language: French.

Headquarters: 68 Avenue de la Libération, Lomé, Togo.

Website: http://www.boad.org (French only)

email: boadsiege@boad.org

President: Abdoulaye Bio-Tchané (Benin).

\section{West African Economic and Monetary Union (UEMOA)}

Founded in 1994, the UEMOA (Union Economique et Monétaire Ouest Africaine) aims to reinforce the competitiveness of the economic and financial activities of member states in the context of an open and rival market and a rationalized and harmonized juridical environment; to ensure the convergence of the macroeconomic performances and policies of member states; to create a common market among member states; to institute a co-ordination for the national sector-based policies; and to harmonize the legislation, especially the fiscal system, of the member states.

Members. Benin, Burkina Faso, Côte d'Ivoire, Guinea-Bissau, Mali, Niger, Senegal, Togo.

Headquarters: 01 B.P. 543, Ouagadougou 01, Burkina Faso. Website: http://www.uemoa.int

President: Soumaïla Cisse (Mali).

\section{Agency for the Prohibition of Nuclear Weapons in Latin America and the Caribbean (OPANAL)}

The Agency (Organismo para la Proscripción de las Armas Nucleares en la América Latina y el Caribe) was established following the Cuban missile crisis to guarantee implementation of the world's first Nuclear-Weapon-Free-Zone (NWFZ) in the region. Created by the Treaty of Tlatelolco (1967), OPANAL is an inter-governmental agency responsible for ensuring that the requirements of the Treaty are enforced. OPANAL has played a major role in establishing other NWFZs throughout the world.

Organization. The Agency consists of three main bodies: the General Conference which meets for biennial sessions and special sessions when deemed necessary; the Council of OPANAL consisting of five member states which meet every two months plus special meetings when necessary; and the Secretariat General.

Members of the Treaty. Antigua and Barbuda, Argentina, Bahamas, Barbados, Belize, Bolivia, Brazil, Chile, Colombia, Costa Rica, Cuba, Dominica, Dominican Republic, Ecuador, El Salvador, Grenada, Guatemala, Guyana, Haiti, Honduras, Jamaica, Mexico, Nicaragua, Panama, Paraguay, Peru, St Kitts and Nevis, St Lucia, St Vincent and the Grenadines, Suriname, Trinidad and Tobago, Uruguay, Venezuela.

Headquarters: Schiller No. 326, 5th Floor, Col. Chapultepec Morales, México, D. F. 11570, Mexico.

Website: http://www.opanal.org

email:info@opanal.org

Secretary-General: Edmundo Vargas Carreño (Chile). 